\title{
SOME ASPECTS OF THE LAW OF RELEASE OF CLAIMS IN IILINOIS
}

Technically speaking, a release at common law is a sealed discharge of an existing claim or obligation, which may have arisen either ex contractu or ex delicto. This definition excludes a common loose usage of the term to refer to discharge of liability by any method, and its alternative correct usage in the field of conveyancing to refer to a certain kind of deed or grant. A release, moreover, may be effective today without a seal.

Operating as it does to destroy all liability with respect to claims purported to be affected thereby, ${ }^{2}$ it is an effective and attractive device which may be used by the harassed obligor to "wipe the slate clean." On the other hand, it is an instrument peculiarly liable to abuse in the hands of the powerful or unscrupulous debtor. The excesses of the ubiquitous insurance adjuster, for example, are too well known to require comment. It is not pretended that obligors of any class have not a moral as well as a legal right to obtain settlements on terms favorable to themselves, especially when their obligations result from merely colorable demands or when the claimant, as is often the case, is the equal or superior of the obligor in bargaining power. But the all too frequent resort to coercive methods to obtain a desired release has resulted in the formulation of a body of law more or less clearly defining the abuses which will invalidate a settlement.

It is well established, for example, that the presence of fraud in procuring the execution of a release will render it unenforceable. The party seeking to procure the release will not be allowed to misrepresent facts in order to procure the signature of the other party, as, for instance, in the frequently recurring cases of deliberate misstatement as to the nature or contents of the instrument signed. ${ }^{3}$ Apparently the party to be released is under no obligation to see to it that the other party read the release, but he may not by any artifice deprive

${ }_{3} 3$ Williston, Contracts $\S$ I820 (r920); Fallon, The Nature of Release, Ir Temple L.Q. I 79 (1937).

2 Rest., Contracts $\$ 402$ (1932); Cairo, Truman \& So. R. Co. v. United States, 267 U.S. 350 (1925); Murphy v. Halleran, 50 Ill. App. 594 (1893); Jackson v. Security Mutual Life Ins. Co., 233 Ill. r6r, 84 N.E. I98 (Igo8); Toffenetti v. Mellor, 323 Ill. 143 , r53 N.E. 744 (I926).

3 Plaintiff was induced to sign a release of liability for the death of her husband by the defendant's misrepresentation that the instrument was a contract whereunder she would be entitled to receive a greater amount if othèr widows received such an amount in compensation for the death of their husbands in the same disaster. Held, invalid. Monahan v. St. Paul Coal Co., I93 Ill. App. 308 (I9I5). See also Lumbermen's Ins. Co. v. Preble, 50 Ill. 332 (r869); IIl. Cent. R. Co. v. Welch, 52 Ill. 183 (I869); Chicago, R.I. \& P.R. Co. v. Lewis, rog III. x20 (I884); Nat'l Syrup Co. v. Carlson, I55 Ill. 2Io, 40 N.E. $49^{2}$ (I895); Pioneer Cooperage Co. v. Ramonowicz, I86 Ill. 9, 57 N.E. 864 (I900); Indiana, D. \& W. R. Co. v. Fowler, 201 Ill. r52, 66 N.E. 394 (r9o3); Ohlmeyer v. American Steel \& Wire Co., r68 Ill. App. I95 (Igr2); Reitz v. Yellow Cab Co., 248 IIl. App. 287 (1928). 
such party of the opportunity or desire to do so.4 The obligor may not take advantage of the other party's inability to read, 5 or his incapacity to understand the instrument at the time of signing by virtue of mental or physical weakness, in order to obtain his signature on a release, the purport of which he does not understand. ${ }^{6}$ The evident deduction from the cases is that, in the absence of deliberate misrepresentation, the party seeking to be released may deal at arms' length with the releasor unless the circumstances are such that the latter is at such a permanent or temporary disadvantage that he is incapable of understanding the significance of the transaction. In such event, the courts will demand that disclosure that is full and adequate in view of the circumstances be made of all facts that would be likely to induce the obligee's decision, and he must understand the effect of the instrument he is asked to sign. He will not be protected, however, if he merely neglected to inform himself of the contents of the instrument or the effect thereof, not having been incapacitated or deceived. ${ }^{7}$ The decision of the court will depend, of course, upon how aggravated the facts of the particular case are. ${ }^{8}$

Such fraud, creating a deception as to the nature or contents of the instrument itself, or consisting of taking advantage of the releasor while he is in such a condition as to be incompetent to contract, is commonly thought of as showing that no release was ever executed in the first place-that the deceived party never consented to the agreement sought to be given effect as a discharge; consequently, it is available at law as a defense to the validity of the instrument. 9 Such matter will commonly appear in the plaintiff-obligee's reply in response to the defendant's answer setting up the release as a defense. Other forms of fraud, such as misrepresentations as to collateral matters independent of the contents or effect of the instrument itself, not necessarily leading to a misconception of the intrinsic elements of the release, formerly were available

4 In Hartley v. Chicago \& Alton R. Co., 214 Ill. 78, 82, 73 N.E. 398, 399 (I905), plaintiff sought to avoid the effect of a release he had signed on the ground, inter alia, that he had not read the instrument. The court said, in overruling this defense, "There was no evidence tending to prove any misrepresentation or trick as to the contents of the instrument, and no trick or device was employed to secure the signature or to prevent plaintiff from reading the release. The very nature and appearance of the instrument were such that a glance would show to any one who could read what its nature was." $C f$. Reitz v. Yellow Cab Co., 248 Ill. App. 287 (1928).

5 Nat'l Syrup Co. v. Carlson, 47 Ill. App. I78 (I893).

${ }^{6}$ Eagle Packet Co. v. Defries, 94 Ill. 598 ( 1880 ) (release obtained by physician from illiterate woman mentally and physically weakened by shock of accident); Chicago, R.I. \& P. R. Co. v. Lewis, Iog Ill. I20 (1884) (semble); Worthey v. C.C.C. \& St. L. R. Co., 25 I Ill. App. 585 (1929); Chicago Union Traction Co. v. Ludlow, I08 Ill. App. 357 (1903) (plaintiff under influence of morphine and unable to understand significance of instrument).

7 See note 5 infra.

${ }^{8}$ See Bonney v. Bonney, 237 Ill. 452, 86 N.E. I048 (rgo9); Smith v. People's Life Ins. Co., 2 I 2 Ill. App. 37 (I9I8); Woodbury v. U.S. Casualty Co., 284 Ill. 227, I20 N.E. 8 (19I8).

9 Note 3 supra. 
to impeach the release only in equity,,$^{10}$ presumably by an affirmative action instituted for that purpose. The rule was apparently otherwise where the release was without a seal. ${ }^{I x}$ Under the Illinois Code, however, such matter presumably can be pleaded in conjunction with that of a "legal" nature, under the provision purporting to abolish the procedural distinctions between law and equity. ${ }^{12}$

The presence of mistake, as to a material fact, as distinguished from fraud in the negotiation and execution of a release, affords grounds for relief in equity, ${ }^{13}$ but the courts are probably more hesitant in this case, inasmuch as the party seeking to be released has not induced the other's action by his own consciously wrongful action, as in the case of fraud. ${ }^{x_{4}}$ For example, if the one party has not by his own fraudulent or coercive conduct sought to obtain the other's signature on the instrument, the fact that the latter, being illiterate or blind or otherwise incapacitated, did not understand the agreement, will not afford grounds for relief for mistake where he did not have someone read or explain it to him, at least where he is not burdened by an additional and extraordinary disability induced by the very circumstances sought to be adjusted, and the other party did not attempt to take deliberate advantage of the disability. ${ }^{\mathrm{IS}} \mathrm{A}$ fortiori, if the releasor is perfectly capable of reading and

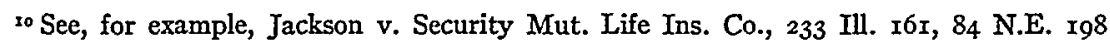
(Igo8), where plaintiff was induced to release husband's insurers on their representations that her claim would be worthless because the husband had made false statements in securing his policy. Also Chicago City R. Co. v. Uhter, 2 I2 Ill. I74, 72 N.E. 195 (1904); Gearty v. L. Fish Furniture Co., 289 Ill. App. 538 (I937).

II Robinson v. Yetter, 238 Ill. 320, 87 N.E. 363 (rgo9).

12 Ill. C.P.A. § 3 I, Ill. Rev. Stat. c. I10, § I55 (1937). But see Gearty v. L. Fish Furniture Co., 289 Ill. App. 538 (1937).

${ }^{13}$ Chicago \& A. R. Co. v. Jennings, II4 Ill. App. 622 (rgo4); Munnis v. Northern Hotel Co., 237 III. App. 5० (Ig25).

Probably the "equitable" defense of mistake can now be pleaded in conjunction with legal defenses in the same action. See note Io supra. On the general problem of relief for mistake see pp. 446-54 supra.

${ }^{14}$ Insofar as the party seeking the release is aware of the other's mistake, his conduct in deliberately taking advantage of it would tend to amount to fraud, and would be covered by rules discussed supra.

${ }^{15}$ Ill. Cent. R. Co. v. Jonte, 13 Ill. App. 424 (1883); Black v. Wabash, St. L. R. Co., III Ill. 35 I (1884); Chicago, R.I. \& P. R. C\& v. Hamler, 215 Ill. 525, 74 N.E. 705 (I905); Guerra v. Rocco, I8I Ill. App. 528 (I9I3); Shulman v. Moser, 284 Ill. I34, IIg N.E. 936 (Igr8).

But apparently a different result may be reached by some courts in special circumstances. See, for example, Whitney \& Starrette Co. v. O'Rourke, I72 Ill. I77, 182,50 N.E. 242, 244 (I898), where the court, in refusing to uphold a release, said, "As to the release . . , it appears to have been intended rather as a receipt for wages due to the appellee at the time it was signed, than as a release of damages suffered on account of the accident in question. . . . It is true that, at the bottom of the receipt and before the signature, appear these words: 'In full for service and damages.' But the evidence shows that the appellee was an ignorant man, and could not read or write, and signed the receipt by making his mark. There is evidence tending to show that he did not understand the paper signed by him to be a release of damages... . 
understanding the terms of the instrument by his own efforts, he will not be relieved because of his failure to do so.

If the mistake is one of "law," usually no relief will be given. ${ }^{16}$ Presumably, however, relief would be afforded as to releases made under such a mistake, where the mistake is induced by one who takes advantage of it, and close relations exist between the parties, so that the one mistaken is entitled to rely.17

While the ignorance of actual injuries suffered by the releasor, or of the seriousness of known injuries is probably not enough, standing alone, to justify rescission of a release for mistake when the instrument was signed with the intent that it was to preclude all liability for existent damages, such ignorance, as a practical matter, will stimulate the courts to seize on any unconscionable conduct of the obligor in procuring the agreement, as a basis on which to predicate relief. ${ }^{18}$

When the efforts to induce the giving of a release become too aggressive, of course, they may amount to duress, which will invalidate releases as well as other types of agreements. ${ }^{x 9}$ Apparently the situation must be so extreme that the coerced party is deprived of his own free will and is subjected to the other's dominance, as the result of an overwhelming fear of imminent personal disaster. ${ }^{20}$ The courts will probably not require a very strong showing of in-

The jury have (not erroneously) found that he did not understand it to be a release." $C f$. Metropolitan Bank v. Godfrey, 23 Ill. 573 (I860); Edward Thompson Co. v. Hunt, 218 Ill. App. 616 (rg2o).

${ }^{16}$ Hendrix v. People, 9 Ill. App. 42 (188I); Williams v. Rhodes, 8x Ill. 57I (1876); Barnett v. Noble, I55 Ill. App. 229 (I910); Kazwell v. Reynolds, 250 Ill. App. I74 (I928). See, for possible qualifications on the rule as stated, pp. 446-47 supra.

${ }^{17}$ See, for example, Sands v. Sands, II2 Ill. 225 ( 1885 ), where a favored son induced his mother to convey her estate to him, upon his assurance that the deed was in the nature of a will and so would not be operative until her death. The deed was set aside. The court treated the case as involving mistake of law. It might well have found actual fraud, and the presence of undue influence, the mother having been old and feeble, may have been a deciding factor. Cf. Eichhorst v. Eichhorst, 338 Ill. I85, I70 N.E. 269 (r930); Cusack v. Cusack, 253 Ill. App. 288 (r929), rev'd 339 Ill. 108, I70 N.E. 84 I (1930).

${ }^{18}$ In Munnis v. Northern etc. Ins. Co., 237 Tll. App. 50 (1925), complainant was injured by falling down an elevator shaft. While lying in the hospital and in a weakened condition, defendant's adjuster procured a release, complainant assuming that his injuries were temporary and not serious. Actually, his hurts were serious and permanent. The release was set aside as made under mistake of a material fact. The decision was obviously influenced by unconscionable conduct of defendant's agent in inducing complainant's action, and by a desire to protect the distressed claimant from making a bad bargain at a time when his powers were impaired. Reluctance to uphold releases obtained in such circumstances is evidenced by courts in other jurisdictions. See 26 Mich. L. Rev. 828 (I928); 33 Minn. L. Rev. 392 (I929); 3 Brooklyn L. Rev. 345 (I934); 2I Iowa L. Rev. 146 (I935).

${ }^{29}$ Spaids v. Barrett, 57 Ill. 289 (I870); Woodbury v. U.S. Casualty Co., 284 Ill. 227 ; I20 N.E. 8 (IgI8).

20 McAldon v. Van Alstine, r35 Ill. App. 396 (I907); Still v. Still, r88 Ill. App. $33 \circ$ (Igr4); Harris v. Flack, 289 Ill. 222, r24 N.E. 377 (I9I9); Cook v. Wolf, 296 Ill. 27, I29 N.E. 556 (rg2r).

Compare the more liberal attitude expressed in Rees v. Schmits, I64 Ill. App. 250 (IgII); Ill. Merchants' Trust Co. v. Harvey, 335 Ill. 284, I67 N.E. 69 (I929). 
timidation, however, in questionable situations where the releasor at the time of signing the instrument was suffering from the effectes of bodily or mental injury, and his resulting weakness was taken advantage of by the other to obtain the release. In Woodbury v. United States Casualty Co., ${ }^{2 x}$ the plaintiff had accidentally shot himself, necessitating the amputation of his foot. While he was still in a dazed and weakened condition as a result of the accident, the defendant insurer's adjuster threatened to have him prosecuted and sent to the penitentiary for attempting to defraud the company through deliberate scheming. The plaintiff signed a release as much to rid himself of the unwelcome visits of the adjuster as to avert the threatened consequences of a refusal to sign. Although the court did not indicate whether the adjuster's conduct was fraudulent or coercive, it is apparent that its refusal to uphold the instrument was influenced by the pressure on the plaintiff. ${ }^{22}$

The conduct of the coercing party need not threaten or affect the personal well-being of the other party. Its effect is equally coercive when the apprehended disastrous consequences will affect the other party's property. In Spaids v. Barrett, ${ }^{23}$ the defendant tied up the plaintiff's perishable foodstuffs by an attachment fraudulently obtained. He then refused to surrender the goods except on condition of plaintiff's remitting to him an amount more than twice what was due and executing a release from all damages. The release so obtained was set aside as having been procured by duress of property. In this situation, however, the courts probably will not be as quick to grant relief as in the situation of the Woodbury case. ${ }^{24}$

All the foregoing grounds of attack on the validity of releases require the 22 284 IIl. 227 , I20 N.E. 8 (1918).

${ }^{22}$ Compare note 6 supra. A mere threat to resort to legal action or process in pursuance of a claim having some foundation in fact, not amounting to abuse of process does not amount to duress. Taylor v. Cottrell, I6 IIl. 93 (1854); McAldon v. Van Alstine, I35 Ill. App. 396 (I907); Kerting v. Hilton, 152 IIl. 658, 38 N.E. 94I (r894); Loan \& Protection Ass'n of Patoka v. Holland, 63 Ill. App. 58 (I895); Kreider v. Fanning, 74 Ill. App. 230 (I897); Gregory v. Gregory, 323 Ill. 380 , I54 N.E. 149 (1926).

${ }^{23} 57$ Tll. 289 (I870).

${ }^{24}$ In Ritchie v. Cherest, 8 Ill. App. 534 (I88I), the plaintiff executed a release of further liability of the defendant for payment of a disputed amount for services rendered, in consideration of immediate payment of part of that amount. His action was necessitated by urgent necessity to pay the claims of pressing creditors. Held, no duress. Cf. Bonney v. Bonney, 237 III. 452 , 86 N.E. 1048 (I908) (no duress established where plaintiff was forced to sign a release in fear of the defendant's successful accomplishment of his threat to take plaintiff's children away from her in a pending divorce proceeding if she did not do so). See also Hartsville Oil Mill v. United States, 27I U.S. 43 (I926), where officers of the federal government threatened to refuse to perform the government's part of contracts for raw materials to be supplied by plaintiff contractors. Plaintiffs were given one hour in which to decide whether to accept this consequence or to execute a compromise agreement at an alleged loss to themselves. The court refused to set this agreement aside for duress.

Duress was originally limited to coercion of the person, its basis being the supposed deprivation of the power of free will. It was later conceded that coercion of property could have the same effect on its owner's mind. Out of this concession came relatively modern rule as to duress of property. See 5 Williston, Contracts, c. 47 (rev. ed. I937). 
existence of abnormal fact situations-the undue pressure brought to bear by the one party on the other, exceeding the limits of permissible bargaining zeal, the conscious attempt to "trick" the releasor into signing the instrument by taking deliberate advantage of his known misconception of the true situation, the releasor's inability to hold up his own end of the negotiations by virtue of personal incapacity, or other facts justifying the courts in bringing the case within traditional fields of law, such as fraud, mistake, or duress. In the absence of such facts, if the parties negotiated from equally advantageous bargaining positions, the release agreement should be upheld. But it is believed that in many cases the individual tort claimant being solicited to release his claims is not in a position ably to defend his own interests even in the absence of coercive or fraudulent conduct on the part of his obligor, especially where that obligor is a powerful business organization, such as a railroad or insurance company. The prospect of a long and costly legal battle with such an opponent, often commanding almost unlimited resources, is enough to deter all but the most courageous or the most vindictive from taking action, especially where a tempting compromise settlement is offered in consideration of a release. It is conceivable that relief might be obtained in equity where gross inadequacy of benefits received or other circumstances render the agreement so unconscionable as to warrant equitable action. ${ }^{25}$

The requirement of consideration for a release ${ }^{26}$ may furnish a bulwark of protection for the claimant, a guaranty that he will not be completely deprived of his claims without some beneficial return therefor. It is true that at common law a sealed release was binding, and like other sealed instruments, required no consideration. ${ }^{27}$ But in Illinois, the common law effect of the seal has been modified, so that it merely "imports" or "furnishes evidence of" or "a presumption of " a consideration. ${ }^{28}$ This effect is apparently conclusive in actions

${ }^{25}$ See Dreyer v. Goldy, 62 Ill. App. 347 (I895), appeal dismissed I7 I Ill. 434, 49 N.E. 560 (1898); Gary v. Newton, 20 IIl. x70, 66 N.E. 267 (I903); Aldrich v. Ederer, 220 Ill. App. 333 (1920); Hustad v. Cerney, 32r Ill. 354, I5I N.E. 87I (I926); McClintock, Equity c. 3 (1936).

${ }^{26}$ Benjamin v. McConnell, 4 Gilm. (Ill.) 536 ( 1847 ); Wilson v. Keller, 9 Ill. App. 347 (r88r); Murphy v. Haileran, 50 Ill. App. 594 (r893). In the Wilson case, it was suggested that a release of a claim could operate as a gift if so intended, if a delivery or formal cancellation of some tangible evidence of the claim could be made. But the later case of Ermold v. Bear, $35^{8}$ Ill. 233 , 193 N.E. 184 ( 1934 ), apparently refutes this possibility. See 9 Tulane L. Rev. $6 \times 5$ (1935).

${ }^{27} 3$ Williston, Contracts $\S I 820$ (I920).

${ }^{28}$ Benjamin v. McConnell, 4 Gilm. (IIll.) 536 (I 847); Parks v. Cadwallader, 53 Ill. App. 236 (1893); Fortham v. Deters, 206 Ill. 159, 69 N.E. 97 (1903); Chamberlin v. Sanders, 268 Ill. 4I, ro8 N.E. 666 (rgr5).

See 3 Univ. Chi. L. Rev. 312, 313 (1936). In New York a comparable alteration of the effect of the seal under $\S 840$ of the Code of Civil Procedure applied only to executory agreements so that a release under seal, being executed, could not be impeached for lack of consideration. Homans v. Tyng, 56 App. Div. 383,67 N.Y. Supp. 792 (I900); Finch v. Simon, 6r App. Div. 139, 70 N.Y. Supp. 36r (rgor). 
at law, however, the presence of a seal precluding any inquiry into the question of consideration for the release in such actions. Thus, such impeachment is possible only in equity, ${ }^{29}$ where total want of consideration may be shown to invalidate a release..$^{30}$ In a case of inadequacy of consideration, so gross as to warrant a finding of fraud, moreover, it is conceivable that equity may set aside the agreement..$^{3 x}$ Although equity will look behind the seal on questions of consideration, and although the payment and acceptance of a lesser sum in satisfaction of a liquidated, undisputed claim ordinarily is a defense to that claim only pro tanto ${ }^{32}$-and the presence of an unsealed release of the whole claim will not change this result ${ }^{33}$ - equity will not invalidate a settlement of such a claim given in consideration of payment of a lesser sum plus a sealed release of the balance, ${ }^{34}$ subject to possible exceptions before pointed out as to the want or gross inadequacy of the consideration.

It would seem that the requirement of a seal furnishes little protection to the claimant importuned for a release by a powerful obligor. At most, it requires a certain degree of formality and deliberation that might have some slight deterent effect on the conduct of the one seeking to be released. Much of even this slight effect has apparently been done away with by the liberal Illinois view as to what constitutes a seal, a scroll, 35 the word "seal," ${ }^{36}$ or the letters "L.S.," 37 being sufficient. Insofar as equity will look behind the seal, however, to inquire into questions of consideration, the necessity of furnishing some sort of consideration for the relinquishment of claims, to some slight

${ }^{29}$ Quincy Horse Railway \& Carrying Co. v. Omer, rog Ill. App. 238 (rgo3); Chicago City Ry. Co. v. Uhter, 212 Ill. r 74, 72 N.E. 195 (I904); Jackson v. Security Mut. Life Ins. Co., 233 III. 16I, 84 N.E. 198 (1908); Killean v. Beaupre, 187 Ill. App. 407 (r914); Hemmick v. B. \& O. S. W. R. Co., 263 Ill. 24I, 104 N.E. 1027 (I9I4); Woodbury v. V.S. Casualty Co., 284 Ill. 227, I20 N.E. 8 (I9r8).

Want of consideration at law is a complete defense to an unsealed release. Killean $v$. Beaupre, 187 Ill. App. 407 (xgr4).

${ }^{30}$ Mills v. Larrance, 186 Ill. 635,58 N.E. 219 (Igoo); Bonney v. Bonney, 237 Ill. 452,86 N.E. 1048 (1909). Contra: as to conveyances under seal: Rendleman v. Rendleman, I56 Ill. 568, 4I N.E. 223 (I895); Calkins v. Calkins, 220 Ill. III, 77 N.E. IO2 (I906); Chamberlin v. Sanders, 268 Ill. $4 \mathrm{r}$, I08 N.E. 660 (I9r5).

${ }^{31}$ Crum v. Sawyer, I32 Ill. 443, 24 N.E. 956 (1890); Schwarz v. Reznick, 257 Ill. 479, 100 N.E. 900 (1913); Chamberlin v. Sanders, 268 IIl. 4I, I08 N.E. 666 (1915); Fisher v. Burks, 274 Ill. 363 , II3 N.E. 7 II (IgI6) (dictum).

${ }^{32}$ Morrill v. Baggott, 157 Ill. 240, 4I N.E. 639 (1895); State Savings Loan \& Trust Co. v. Stewart, 65 IIl. App. 39I (1895); Jackson v. Security Mut. Life Ins. Co., 233 Ill. I6I, 84 N.E. I98 (1908); Seidman v. Chicago Eye Shield Co., 267 Ill. App. 77 (I932). (I893).

${ }_{33}$ Benjamin v. McConnell, ${ }_{4}$ Gilm. (Ill.) 536 (1847); Murphy v. Halleran, 5o Ill. App. 594

${ }^{34}$ Capital City Mut. Fire Ins. Co. v. Detwiler, 23 Ill. App. 656 (1887); Martin v. White, 40 IIl. App. 28I (I890).

35 Eames v. Preston, 20 Ill. 389 ( 1858$)$.

${ }^{36} \mathrm{Jackson}$ v. Security Mut. Life Ins. Co., 233 Ill. $16 \mathrm{I}, 84$ N.E. I98 (1908).

${ }^{37}$ Aukeny v. McMahon, 4 Ill. x2 (I84I). See Ill. Rev. Stat., I935, c. 29, § x. 
extent will prevent the imposition of too onesided a bargain on the releasing party. This effect will, of course, be amplified where the instrument does not purport to be sealed at all.

The prevailing trend of the times, however, seems to be in the direction of doing away with the requirement of consideration, in deference to a feeling that agreements, seriously made, should be binding ex proprio vigore. ${ }^{38}$ Some jurisdictions, for example, treat receipts, especially if written, as operative to discharge liability for a greater sum in payment of a smaller. ${ }^{39}$ This tendency has been reflected in the Uniform Written Obligations Act, framed by Williston and recommended by the Commissioners on Uniform Laws, providing that "A written release or promise hereafter made and signed by the person releasing or promising shall not be invalid or unenforceable for lack of consideration, if the writing also contains an additional express statement in any form of language, that the signer intends to be legally bound." ${ }^{0}$ A comparable provision recommended by the Law Revision Commission of New York and adopted in that state reads, "A written instrument, hereafter executed, which purports to be a total or partial release of all claims, debts, demands, or obligations, or a total or partial release or discharge in whole or in part of a mortgage, lien or charge upon personal or real property, shall not be invalid because of the absence of consideration or of a seal." ${ }_{4 \mathrm{I}}$ This section, of course, in doing away with the requirement of consideration and seals destroys what beneficial effect they may have had in equalizing the bargaining positions of releasor and obligor, and substitutes therefor the sole requirement of a writing.

This abolition of the doctrine may be a very healthy phenomenon in the law of contracts. When parties in approximately equal positions seriously enter into a deliberate consensual relationship their intentions without more should be validated.42 But when one of the parties is at a serious bargaining disadvantage, the requirement of consideration may well be a safeguard, however inadequate, against the imposition of unfair agreements. Inequality of position will very frequently be the case where releases executed by tort claimants

${ }^{38}$ See-Ashley, Doctrine of Consideration, 26 Harv. L. Rev. 429 (r9r3); Lorenzen, Causa and Consideration in Contracts, 28 Yale L. J. 621 (r9I9); Sharp, Notes on Contract Problems and Comparative Law, 3 Univ. Chi. L. Rev. 277 (I936).

This trend is especially apparent in the formulation of the modern rule of promissory estoppel. See pp. 464-7I supra.

${ }^{39}$ See 17 Iowa L. Rev. 102 (1931).

${ }_{40}^{40}$ Uniform Laws Ann. 43I (I932). To date, this act has been adopted only in Pennsylvania and Utah.

4I Second Annual Report of the Law Revision Commission, State of New York 69, 78 (I936); Consol. Laws (N.X.) c. 222, § 243, p. 545 (1936).

42 Compare the doctrine of "causa" in the Civil Law, Lorenzen, op. cit. supra note 38. 
are involved. True, consideration is a very poor bulwark of safety. Tort claims being usually unliquidated, the payment of any sum will operate as a satisfaction, ${ }^{43}$ and ordinarily its adequacy will not be questioned,44 so that the claimant may have to be satisfied with a negligible return for his claims. Perhaps a better solution would be a requirement of some sort of a notorization or acknowledgment of the release before a public official, who would, as a condition of authentication, examine into the circumstance and require that the agreement shall have been fairly and understandingly made, without undue pressure or deception. 45 Perhaps this requirement should not be extended to releases of claims arising out of ordinary consensual relationships. $4^{6}$ In such cases, the parties' conduct in voluntarily creating the relationship is tantamount to an admission that they are willing to rely on their own resources exclusively in protecting their own interests. In the case of releases of claims that have not been created volitionally, however, no willingness of the parties to rely upon their own bargaining powers in the adjustment stage reasonably can be inferred. In the usual case of a tort claim, the relationship of the parties is thrust upon them without consent, and the obligee may well need the protection of a rule similar to the one suggested, to prevent impositions by the more powerful obligor, with whom the releasor would never attempt to deal consensually in ordinary circumstances. Conceivably, releasors would find more adequate protection not in the development of new rules, but in a broader application of those already developed, such as fraud, duress, mistake, and equitable relief for inadequacy of consideration.

\footnotetext{
43 Hayes v. Mass. Mut. Iife Ins. Co., I25 Ill. 626, I8 N.E. 322 (I888); Coey v. C. A. Coey \& Co., I50 IIl. App. 296 (I909); Winter v. Meier, I5I Ill. App. 572 (Ig09).

44 Notes 25, 29 supra. See Crum v. Sawyer, I32 Ill. 443, 24 N.E. 956 (I890); Schwarz v. Reznick, 257 Ill. 479, I00 N.E. 900 (I9I3); Kaufman v. Sorrels, I64 Ill. App. 324 (I9II); Hustad v. Cerney, $32 x$ Ill. 354, x5I N.E. 87 r (1936).

${ }_{45}$ Subject to the qualifications imposed by the doctrine of causa, gratuitous releases are recognized in civil law countries. Usually, however, all argeements conferring a gratuity are subject to special requirements of form, such as authentication by a notary or judge. See German Civil Code $\$ 518$; French Civil Code art. 931; Italian Civil Code art. ro56. It has been held in France that releases are not subject to these requirements. Lorenzen, op. cit. supra note 38 , at 639 et seq.

${ }^{4}$ Where, however, as in many insurance contracts, the parties are in such unequal bargaining positions that one party thereto cannot adequately protect his own interests the requirement suggested should apply.
} 